\title{
Engineering Skills and Knowledge Related to nZEB Construction
}

\author{
Victor Jose Torrejon Marina*, Talat Munshi \\ UNEP DTU Partnership \\ Mitigation Analysis \& Data Management \\ Copenhagen, Denmark
}

\begin{abstract}
The buildings sector is the largest energydemanding and polluting sector in the global economy. The implementation of nearly Zero Energy Buildings contributes to reducing energy use and climate change. To support this construction there is a need for educating professionals with the required skills and competencies on energy-efficient buildings. This paper reports on the necessary knowledge to be acquired by engineers to deliver nZEB projects. Here, we identify the entire set of nZEB features described by the European Commission through the EPBD and highlight the concepts to be imparted for each of these technical features. We also present a methodology for analysing nZEB content in university curriculum and contributes to the continuing sustainability education discourse. Thus, it is hoped this study will inform education planners and researchers for gaining knowledge on nZEB teaching.
\end{abstract}

Keywords—energy efficiency, buildings, nZEB, skills, academic curricula, engineering

\section{INTRODUCTION}

Actual patterns of energy supply and use are unsustainable economically, environmentally and socially. Despite efforts to reduce greenhouse gases emissions, the world's energy supply still is by and large as carbon-intensive as it was two decades ago [1]. Without decisive actions and a population growth projection, energy-related emissions of carbon dioxide will be more than double by 2050. This massive energy use and consequent high pollution have changed the climate patterns which they have already affected the lives of communities, eco- systems and economies all over the world. Additionally, the dependency on a limited energy source as fossil fuels and higher energy demand have triggered concerns over the security of the supplies [2]. Thus, one of the measures to be placed is the transformation of the energy industry with a view to accelerating the reduction of global greenhouse gas emissions to provide a sustainable future habitat. The Paris Agreement aims to limit the rise in the average global temperature to less than $2^{\circ} \mathrm{C}$ above pre- industrial levels to pursue efforts to limit the temperature increase to $1.5^{\circ} \mathrm{C}$ above pre-industrial levels [3].

Within this context, the buildings sector is the largest energy- demanding sector in the global economy. Including execution and operation phases, the building sector constitutes $36 \%$ of the total global energy demand and $39 \%$ of global carbon dioxide emissions [4]. Also, buildings consume 55\% of global electricity, what it requires high capacity and infrastructure for the power sector, which is critical in some countries [5].

Strategies and policies on buildings must deliver measures to change the present impact on energy use and environment. The transformation to an energy-efficient and low-carbon buildings is crucial to achieving global ambitions to mitigate climate change. If new near-zero energy construction and deep renovations in existing buildings take place during the next decade, the sector's energy consumption can decrease by $35 \%$ to 2050, yet with double of global floor area [1]. Technologies already exist that would allow the buildings sector to be more energy-efficient and sustainable [5]. Space heating can be improved by better insulation, refurbishments of old buildings, design considerations and more efficient equipment like heat pumps. A similar strategy to cut down cooling energy demand could be applied by insulation and better energy performance devices for air conditioning [1]. Apart of HVAC systems, other measures can be considered in the building as the envelope, domestic hot water, air infiltration, natural ventilation, daylighting, built-in lighting installation, position and orientation of the building, indoor and outdoor climate, passive solar systems and solar protection [6]. By considering these elements in the design phase or restoration projects, energy savings in indoor spaces are achievable. On the other hand, this energy use reduction would enable to lower the impact on the power system, to dimension the electricity capacity and to integrate renewable energy alternatives [1].

The need for sustainable development has changed the entire buildings sector in some parts of the world as Europe. This change has implicated the integration of energy efficiency knowledge in education programmes. For instance, engineering 
schools have updated their old academic curricula and developed new study plans following sustainable requirements. As a result, there are engineers in today's market working on projects where factors of energy savings, indoor air quality and environmental concerns are included. However, the situation in many other countries is different. There is a scarcity of professionals with the proper knowledge and skills on nearly zero energy building, nZEB. Generally, the present university system does not generate this type of professionals and forces to students to acquire this knowledge through seminars, online or abroad. This fact hinders a complete green transformation across the entire sector, and eventually, to deliver sustainable building projects.

As said earlier, there are already university programmes providing the appropriate skills and knowledge and can be applicable to other universities. This work identifies the required skills regarding nZEB and presents a methodology to evaluate current programmes or generate new study plans. An example of this methodology application is carried out to four engineering bachelor study plans. It enables to contrast and to discuss different potential improvements for programmes selected in this work.

\section{METHODOLOGY}

The first method used is internet search. Search engines are internet-based tools that searches an index of website documents, website pages, online content or media for a particular phrase, term, text or image specified by the user [7]. Information is collected from websites of universities, international organizations, public institutions and scientific online libraries.

The second method used is content analysis. The type of data extracted from university websites is qualitative. Content analysis has the goal to reduce the bulk of information in different categories by using a code. A system code for the classification of nZEB skills is developed based on later chapters. These categories allow to construct a further comparison and discussion between different academic programmes and their contents for each nZEB skill. For content analysis, the steps to follow in this process are described below in Table I [8]:

TABLE I. CONTENT ANALYSIS

\begin{tabular}{|c|c|}
\hline Steps of content analysis & Description \\
\hline $\begin{array}{l}\text { 1. Define the research } \\
\text { questions to be addressed by } \\
\text { the content analysis }\end{array}$ & $\begin{array}{l}\text { Which are the skills related to nZEB? Which are } \\
\text { the concepts related for each nZEB skill? }\end{array}$ \\
\hline $\begin{array}{l}\text { 2. Define the population } \\
\text { from which units of text are } \\
\text { to be sampled }\end{array}$ & $\begin{array}{l}\text { Search for policies, regulations and university } \\
\text { programmes related to nZEB teaching, } \\
\text { webpages of Civil engineering and Building } \\
\text { technology engineering schools are visited. } \\
\text { Next, a set of } \\
\text { keywords is employed to determine a potential } \\
\text { programme candidate. These }\end{array}$ \\
\hline
\end{tabular}

Table 1. Cont.

\begin{tabular}{|c|c|}
\hline Steps of content analysis & Description \\
\hline & $\begin{array}{l}\text { words are "sustainable buildings", "nearly Zero } \\
\text { Energy Building", "energy-efficient buildings", } \\
\text { "sustainable construction", "ecological } \\
\text { construction", "energy savings" and "indoor } \\
\text { climate". Potential candidate programmes must } \\
\text { include these terms in the programme } \\
\text { description, learning objectives and study plan. } \\
\text { Finally, courses contents are collected if they } \\
\text { relate to some of the required skills for nZEB } \\
\text { engineers. }\end{array}$ \\
\hline $\begin{array}{l}\text { 3. Define the sample to } \\
\text { be included }\end{array}$ & $\begin{array}{l}\text { Collect the description of syllabus from } \\
\text { relevant courses }\end{array}$ \\
\hline \multicolumn{2}{|c|}{$\begin{array}{l}\text { 4. Define the context of the Identify nZEB definition and its elements. Then, } \\
\text { generation of the document } \begin{array}{l}\text { university study plans are chosen. For this work, } \\
\text { there are four study cases } \\
\text { from four bachelor programmes. }\end{array}\end{array}$} \\
\hline $\begin{array}{l}\text { 5. Define the sample units of } \\
\text { analysis }\end{array}$ & $\begin{array}{l}\text { Sampling units put texts into categories of } \\
\text { nZEB skills in contents courses. }\end{array}$ \\
\hline $\begin{array}{l}\text { 6. Decide the code to be } \\
\text { used in the analysis }\end{array}$ & $\begin{array}{l}\text { The code to use is the whole set of nZEB skills } \\
\text { for engineers identified }\end{array}$ \\
\hline $\begin{array}{l}\text { 7. Construct the } \\
\text { categories for analysis }\end{array}$ & $\begin{array}{l}\text { Each category corresponds to each nZEB } \\
\text { skill }\end{array}$ \\
\hline $\begin{array}{l}\text { 8. Conduct the coding and } \\
\text { categorizing of the } \\
\text { data }\end{array}$ & $\begin{array}{l}\text { dEvery programme is broken down according the } \\
\text { code and categories } \\
\text { developed in step } 7\end{array}$ \\
\hline 9. Conduct the data analysis & $\begin{array}{l}\text { A comparison between courses for each nZEB } \\
\text { skill from the selected university } \\
\text { programmes is carried out }\end{array}$ \\
\hline 10. Summarizing & $\begin{array}{l}\text { Relevant concepts from nZEB programmes are } \\
\text { highlighted }\end{array}$ \\
\hline $\begin{array}{l}\text { 11. Making } \\
\text { inferences }\end{array}$ & $\begin{array}{l}\text { The target of early comparisons is to highlight } \\
\text { and to summarize all the concepts related to any } \\
\text { enZEB skill in the four-university study plans. } \\
\text { This allows presenting suggestions and } \\
\text { recommendations to upgrade existing } \\
\text { programmes or create new study lines. }\end{array}$ \\
\hline
\end{tabular}

\section{LITERATURE REVIEW}

Currently, there are many ways to name or address the fact of energy efficiency in buildings. Several public and private institutions provide their own specific definition and requirements for sustainable buildings. Among these institutions, the European Commission established Energy Performance of Buildings Directive (EPBD) to articulate any plan, action and innovation regarding energy consumption in buildings, along with the reduction of greenhouse gases emissions. By the implementation of nZEB concept, it is expected to achieve by 2050 a high energy efficiency performance, to decarbonize building stock, to create long term stable environment for investments and to allow consumers and business to have better access to systems to save energy and money. EPBD defines the concept of a nZEB as " "nearly zeroenergy building' means a building that has a very high energy performance, as determined in accordance with Annex I. The nearly zero or very low amount of energy required should be covered to a very significant extent by energy from renewable sources, including energy from renewable sources produced onsite or nearby" [6]. As it is described in the Annex I, to calculate 
the energy performance of a nearly Zero Energy Building takes into consideration the next aspects:

- Thermal capacity, insulation, passive heating, cooling elements and thermal bridges;

- Heating installation and hot water supply, including their insulation characteristics;

- Air-conditioning installations;

- Natural and mechanical ventilation which may include airtightness;

- Built-in lighting installation (mainly in the nonresidential sector);

- The design, positioning and orientation of the building, including outdoor climate;

- Passive solar systems and solar protection;

- Indoor climatic conditions, including the designed indoor climate;

- Internal loads.

\section{IDENTIFICATION OF CONCEPTS RELATED TO EACH NEARLY ZERO ENERGY BUILDING SKILL}

Building elements and systems addressed by EPBD can be grouped in nine different categories, which represent the whole range of knowledge related to nZEB professionals. Likewise, these skill categories include the next concepts to be learnt in order to master such skill:

1) $n Z E B$ general concepts: energy building performance, building codes and building regulation and certifications [9].

2) Sustainable architectural design: orientation and layout of the building to reduce/maximize the absorption of heat from the sun and daylight. Also, space allocation in relation to daylight is a relevant concept to acquire in this category [10].

3) Indoor comfort, Heat-Air-Moisture (HAM) and climate: thermal comfort [11], internal loads [12], indoor air quality, heat-air-moisture, climate and weather [13].

4) Envelope design: thermal bridges, waterproofing, airtightness, insulation [14], windows [15], sun shading devices, roof design to provide overhangs, green roofs and walls [10].

5) Ventilation system: natural and mechanical ventilation [15] with a special attention to heat and moisture recovery [17].

6) Heating and cooling system: passive and active design systems [18], thermal environment, internal heat sources, dehumidification systems, thermal control zones, centralized (district heating) and decentralized systems [13]

7) Domestic hot water: DHW system design [19].

8) Ligthing: physics of light, natural lighting and artificial lighting systems [13].
9) Acoustics: physics of sound, acoustics in design, process sound insulation and sound absorbing materials [20].

\section{ACADEMIC TOOL}

This set of skills presented offers a guideline to create new study lines to impart nearly Zero Energy Buildings in engineering schools. Likewise, this 9-category classification delivers a methodology to revise and to update actual engineering university programmes to guarantee the teaching of the whole range of knowledge related to energy efficiency and indoor climate in built-environments. A study plan that targets to train engineers in energy efficiency and indoor comfort should include the whole range of presented nZEB skills. Following, this method is applied for four different study plans across Europe. This set of skills is used as the code referred previously to carry out the content analysis of each programme and course.

TABLE II. ACADEMIC ANALYSIS OF FoUR NZEB STUDY Plans

\begin{tabular}{|c|c|c|c|c|}
\hline \multirow[t]{2}{*}{ Category skill } & \multicolumn{4}{|c|}{ University } \\
\hline & $D T U^{a}$ & $T U M^{b}$ & $U P M^{c}$ & Chalmers $^{d}$ \\
\hline nZEB general concepts & $\mathrm{X}$ & $\mathrm{X}$ & $X$ & $X$ \\
\hline Sustainable arch design & $X$ & $X$ & & $X$ \\
\hline $\begin{array}{l}\text { Indoor comfort, HAM and } \\
\text { climate }\end{array}$ & $X$ & $\mathrm{X}$ & $\mathrm{X}$ & $\mathrm{X}$ \\
\hline Envelope design & $X$ & $\mathrm{X}$ & $X$ & $\mathrm{X}$ \\
\hline Ventilation & $X$ & & $\mathrm{X}$ & $\mathrm{X}$ \\
\hline Heating and cooling & $X$ & & $X$ & \\
\hline Domestic hot water & $\mathrm{X}$ & & & \\
\hline Ligthing & $X$ & $X$ & $X$ & \\
\hline Acoustics & $X$ & $\mathrm{X}$ & & $\mathrm{X}$ \\
\hline & & 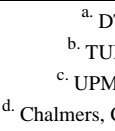 & $\begin{array}{l}\text { U, Denmark } \\
\text { 1, Technical L } \\
\text { University P } \\
\text { halmers Univ }\end{array}$ & $\begin{array}{l}\text { echnical University } \\
\text { iversity of Munich } \\
\text { ytechnic of Madrid } \\
\text { rsity of Technology }\end{array}$ \\
\hline
\end{tabular}

The evaluation of these study plans reflects the present situation of nZEB teaching in each bachelor programme in comparison with the others. Gaps on academic curricula can be detected and filled out by referring other's example. Thus, it can be observed that DTU excels over the rest of programmes. This is the result to not include only nZEB concept but the pedagogy approach and duration. The rest of study plans combines nZEB teaching with other civil engineering topics, turning out in lower specialization.

\section{CONCLUSIONS}

This work identifies the definition and features regarding a nearly Zero Energy Building. Energy Performance Building Directive of European Commission defines an nZEB as a building that has a very high energy performance. Additionally, EPBD mentions the elements and systems to consider regarding energy saving measures in a building, which are classified in nine categories: nZEB general concepts, sustainable architectural design, indoor comfort and HAM and climate, envelope design, ventilation systems, heating and cooling system, domestic hot water, lighting and acoustics. Each specific category covers a range of concepts related to them 
which must be included in the courses' contents of nZEB engineering programmes. This set of nine general skills delivers a guideline to compose new bachelor and master programmes to train future engineers on energy efficiency and indoor climate. Also, this method provides an opportunity for current study plans to evaluate and to update some learning contents.

\section{ACKNOWLEDGMENT}

Victor would like to thank to the organization of 6th UPI TVET Conference 2020 in conjunction with the $5^{\text {th }}$ ICIET RMUTT Thailand, to his thesis's supervisors Talat Munshi and Sven Svendson and UNEP DTU Partnership (UDP) for this opportunity and support.

\section{REFERENCES}

[1] IEA, "Perspectives for the Clean Energy Transition. The critical role of Buildings," IEA, Paris, 2019.

[2] IEA, "Technology Roadmap. Energy efficient building envelopes," International Energy Agency, Paris, 2013.

[3] UN, "PARIS AGREEMENT," UN, Paris, 2015.

[4] UNEP, " UN Environment and International Energy Agency (2017): Towards a zero-emission, efficient, and resilient buildings and construction sector. Global Status Report 2017," UNEP, Paris, 2017.

[5] IEA, "Building energy codes and standards by country, 2018," 2019. [Online]. Available: https://www.iea.org/reports/trackingbuildings/building-envelopes\#abstract.

[6] European Commission, "Directive 2010/31/Eu Of The European Parliament And Of The Council of 19 May.

2010 on the energy performance of buildings," EUROPEAN PARLIAMENT, Brussels, 2010.

[7] S. \&. A. A. \&. I. H. Mehmood, "Internet Searching Technique, Information Retrieval and the impact on Search engine," 2017.

[8] L. Cohen, L. Manion and K. Morrison, Research Methods in Education, Oxon: Routledge, 2007.
[9] J. Lausten, "Energy requirements in building codes, energy efficiency policies for new buildings," OECD/IEA, Paris, 2008.

[10] ILO, "Skill and occupational needs in Green Buildings 2011," European Commission, Geneve, 2011.

[11] A. Steinmann, P. Wargocki and B. Rismanchi, "Ten questions concerning green buildings and indoor air quality," Buildings and enviroment, vol. 112, pp. 351-358, 2016.

[12] B. Jones and C. Molina, "Indoor Air Quality," Elsevier, pp. 197-207, 2017.

[13] N. Lechner, Heating, Cooling, Lighting. Sustainabible methods for architects. Fourth Edition, New Jersey: John Wiley \& Sons, Inc., Hoboken, 2015.

[14] M. Rabani, H. B. Madessaa and N. Nordb, "A state-of-art review of retrofit interventions in buildings towards nearly zero energu building," in 9th International Conference on Sustainability in Energy and Buildings, SEB-17, 5-7 July 2017,, Chania, Crete, Greece, 2017.

[15] B. P. Jelle, A. H. A. Gustavsen, D. Arasteh, H. Goudey and R. Hart, "Fenestration of today and tomorrow: A state-of-the-art review and future research opportunities,", Solar Energy Materials \& Solar Cells 96 (2012), p. 1-28, 2010.

[16] B. Chenari, J. D. Carrilho and M. G. d. Silva, "Towards sustainable, energy- efficient and healthy ventilation strategies in buildings: A review," Renewable and Sustainable Energy Reviews, vol. 59, pp. 1426$1447,2016$.

[17] D. O'Connor, J. K. S. Calautit and B. R. Hughes, "A review of heat recovery technology for passive applications," Renewable and Sustainable Energy Reviews, vol. 54, pp. 1481-1493, 2016.

[18] I. Oropeza-Perez and P. A. Østergaard, "Active and passive cooling methods for dwellings: A review," Renewable and Sustainable Energy Reviews - 2018, Volume 82, pp. 531-544, 2018.

[19] M. Pomianowski, H. Johra, A. Marszal-Pomianowska and C. Zhang, "Sustainable and energy-efficient domestic hot water systems: A review," Renewable and Sustainable Energy Reviews, vol. 128, 2020.

[20] A. Milo, "The acoustic designer: Joining sounscape and architectural acoustics in architectural design education," Building Acoustics, vol. 27(2), p. 830122, 2020. 